VARIANCE ACCOUNTING 


\section{Other books in the ICMA series}

P UB L IS HED

H. K. Jaeger

THE STRUCTURE OF CONSOLIDATED ACCOUNTING

F OR T H COM I N G

R. J. Briston

INTRODUCTION TO ACCOUNTING AND FINANCE

Frank Osborn

COSTING AND CONTROL FOR MATERIALS 


\title{
Variance Accounting
}

\author{
Ernest Laidler, F.C.M.A.
}

$\mathbf{M}$

Published in association with the

Macmillan Education 
All rights reserved. No part of this publication may be reproduced or transmitted, in any form or by any means, without permission.

First edition 1976

Reprinted 1979, 1983

Published by

THE MACMILLAN PRESS LTD

in association with

The Research Foundation of the Institute of

Cost and Management Accountants

London and Basingstoke

Associated companies in Delhi Dublin

Hong Kong Johannesburg Lagos Melbourne

New York Singapore and Tokyo

ISBN 978-0-333-19609-0

DOI 10.1007/978-1-349-15687-0

ISBN 978-1-349-15687-0 (eBook)

Set in IBM Press Roman by

Type Practitioners Ltd, Sevenoaks, Kent.

This book is sold subject to the standard conditions of the Net Book Agreement.

The paperback edition of this book is sold subject to the condition that it shall not, by way of trade or otherwise, be lent, resold, hired out, or otherwise circulated without the publisher's prior consent, in any form of binding or cover other than that in which it is published and without a similar condition including this condition being imposed on the subsequent purchaser. 


\section{To Helen}




\section{Contents}

List of Figures and Statements ix

Foreword $\quad$ xi

Preface xiii

\section{Part One Measurement of Costs and Profit}

Introduction The Profit Motive in Industry 3

1 Methods, Principles and Techniques 5

$\begin{array}{ll}\text { Cost and profit structure } & 5\end{array}$

Basic costing methods $\quad 11$

$\begin{array}{ll}\text { Superimposed principles and techniques } & 12\end{array}$

2 Evolution of Variance Accounting 14

$\begin{array}{ll}\text { Actual cost ascertainment } & 14\end{array}$

$\begin{array}{ll}\text { Standard costing } & 15\end{array}$

Budgetary control $\quad 15$

The unified technique $\quad 15$

Budgetary control in isolation $\quad 16$

$\begin{array}{ll}\text { Job order industries } & 16\end{array}$

$\begin{array}{ll}\text { Mass-production industries } & 17\end{array}$

$\begin{array}{ll}\text { Brief outline of control through variance accounting } & 17\end{array}$

$\begin{array}{ll}\text { Information for management - the exception principle } & 18\end{array}$ 


\section{Part Two Setting Targets}

3 Long-and Short-Term Planning 23

$\begin{array}{ll}\text { Enterprise policy - long-term planning } & 23\end{array}$

$\begin{array}{ll}\text { Current budgets } & 24\end{array}$

4 Functional Budgets 31

$\begin{array}{ll}\text { Sales budget } & 31\end{array}$

Quantitative production budget $\quad 34$

$\begin{array}{ll}\text { Production cost budget and standard product costs } & 40\end{array}$

General administration expense budget $\quad 54$

$\begin{array}{ll}\text { Marketing expense budget } & 54\end{array}$

Research and development budget $\quad 59$

$\begin{array}{lr}\text { Capital expenditure budget } & 59\end{array}$

$\begin{array}{ll}\text { Purchase budget } & 60\end{array}$

$\begin{array}{ll}\text { Cash-flow budget } & 62\end{array}$

5 Summaries, Revisions and Adjustments 65

$\begin{array}{ll}\text { Summary budgets } & 65\end{array}$

$\begin{array}{ll}\text { Budget adjustments } & 68\end{array}$

\section{Part Three Accounting for Variances}

6 Theory and Practice of Variance' Analysis 75

$\begin{array}{ll}\text { Theoretical aspects } & 75\end{array}$

$\begin{array}{ll}\text { Variance analysis in practice } & 87\end{array}$

$\begin{array}{ll}\text { Reporting variances } & 93\end{array}$

7 Cost and Financial Accounts - The Link 98

$\begin{array}{lr}\text { Älternatives } & 98\end{array}$

$\begin{array}{lr}\text { Interlocking accounts } & 98\end{array}$

$\begin{array}{ll}\text { Integral accounts } & 104\end{array}$

Manufacturing, trading and profit and loss accounts 105

8 Absorption Costing 106

Evolution of the concept $\quad 106$

$\begin{array}{ll}\text { Budgeted fixed overhead } & 107\end{array}$

$\begin{array}{ll}\text { Standard costs } & 107\end{array}$

$\begin{array}{ll}\text { Monthly budget } & 107\end{array}$

Variance analysis $\quad 113$

9 The Choice - Absorption or Marginal Costing? 121

$\begin{array}{ll}\text { Introduction } & 121\end{array}$

Dialogue $\quad 122$

$\begin{array}{ll}\text { Conclusion } & 132\end{array}$

$\begin{array}{ll}\text { Index } & 133\end{array}$ 


\section{List of Figures and Statements}

FIGURES page

1. The elements of cost 6

2. Methods, principles and techniques of management 10 accounting systems

3. Co-ordination of functions 25

4. Interrelationships of variances (marginal concept) 77

5. Interrelationships of variances (absorption concept) 112

\section{STATEMENTS}

1. Ascertainment of economic ordering quantity 50

2. Standard cost sheet (marginal concept) 51

3. Summary of stock values 66

4. Profit budget 67

5. Primary variance analysis (marginal concept) 80

6. Variances ascertained in relation to individual products 88

7. Departmental operating statement 95

8. Monthly profit statement 97

9. Financial final accounts 105

10. Apportionment and absorption of fixed production overhead 108

11. Standard cost sheet (absorption concept) 109

12. Primary variance analysis (absorption concept) 110-1 


\section{Foreword}

The use of budgets and standard costs in conjunction with the process of variance analysis has been widely accepted for some time but the term 'variance accounting' is new. It was introduced in Terminology of Management and Financial Accountancy (published by the Institute in 1974) at the suggestion of the author, who devised the contextual structure of the management accountancy section and framed the definitions in that section of the terminology.

From his wide knowledge of industrial accounting and his teaching experience Mr Laidler has written a book which should be invaluable to managers as well as students of accountancy.

Both theoretical and practical aspects of the subject are treated in this book and the feasibility of theories is critically examined.

An understanding of the technique of variance accounting contributes to cost control for profit improvement which is vitally important especially, in the current economic circumstances. This book provides a comprehensive outline of the technique and should prove of value to accountants and managers in industry concerned with profit improvement.

President 


\section{Preface}

Towards the end of a long career in the field of industrial accounting which ranged over a wide variety of manufactures I turned to the teaching of cost and management accountancy with particular reference to Part IV of the ICMA examinations. In teaching I was deeply conscious of the difficulties experienced by students in relating academic theory to practical applications so the invitation to write this book brought with it an opportunity to attempt to bridge this gap, at least within the context of variance accounting.

The overall concept comprising the use of budgets and standard costs in connection with the process of variance analysis is widely accepted but the term 'variance accounting' is new. It is defined on page 13 of this book and the reasons for its adoption are explained in Chapter 2.

Each management accounting system, whether it incorporates the technique of variance accounting or not, must be tailored to fit a particular combination of background conditions and comply with the special requirements and preferences of the management concerned. These factors differ so widely among industrial organisations that it is perhaps true to say that each undertaking is unique. Whilst it may specialise in a particular range of commodities or services there is usually a wide variety within that range and its functional structure is likely to be complex.

To endeavour to present a system complete in every detail and devised to accommodate the myriad ramifications of an actual organisation would not best serve the readers' interests. Those who would recognise the model as closely akin to the organisations in which they 


\section{xiv Preface}

were personally engaged would represent a tiny minority and, to the rest, the intimate concern with technicalities relating to a type of manufacture in which they had no interest, and the proliferation of figurework necessitated by the product variety, would be tedious in the extreme and there would be no compensating advantages.

Many basic principles and procedures have general application but every effort has been made to explain where they vary between contrasting types of activity. Where it has been necessary to present a series of interrelated working examples these have been identified with an imaginary company - Lingrove Instruments Limited - which, happily, has but two production cost centres and manufactures only two products. This simplicity in no way invalidates the examples.

Despite the considerable diversity of background features to be found in industry, there is sufficient common ground among manufacturing undertakings to admit many valid generalisations. Service industries, on the other hand, differ so markedly from the manufacturing sector and indeed from each other that each merits individual treatment in a separate book. In this book, therefore, the emphasis is substantially on manufacture.

Definitions of cost and management accountancy terms are taken from the Institute's publication Terminology of Management and Financial Accountancy. 